\title{
Effect of Rhodomonas salina addition to a standard hatchery diet during the early ontogeny of the scallop Pecten maximus
}

\author{
Réjean Tremblay ${ }^{a,{ }^{*}}$, Simon Cartier ${ }^{a}$, Philippe Miner ${ }^{b}$, Fabrice Pernet $^{c}$, Claudie Quéré ${ }^{b}$, \\ Jeanne Moal $^{\mathrm{b}}$, Marie-Louise Muzellec ${ }^{\mathrm{d}}$, Michel Mazuret ${ }^{\mathrm{b}}$ and Jean-François Samain ${ }^{\mathrm{b}}$ \\ ${ }^{a}$ Institut des Sciences de la Mer, Université du Québec à Rimouski, Rimouski, QC, Canada G5L 3A1 \\ ${ }^{\mathrm{b}}$ DRVIA, Laboratoire de Physiologie des mollusques, IFREMER Centre de Brest, Plouzané, France \\ ${ }^{\mathrm{c}}$ Institut de Recherche sur les Zones Côtières, Université de Moncton, Shippagan, NB, Canada E8S \\ ${ }^{\mathrm{d}}$ Ecloserie du Tinduff, Comité Local des Pêches Maritimes du Nord-Finistère, Plougastel-Daoulas, \\ France 29470
} 29280 $1 \mathrm{~J} 2$

*: Corresponding author : rejean_tremblay@uqar.qc.ca

\begin{abstract}
:
The main objective of this study was to identify algal diets that maximize the survival and growth and alter the biochemical content of Pecten maximus larvae with the aim of improving metamorphosis. We also evaluated the potential of the cryptophyceae Rhodomonas salina as a food source for these larvae. Two flagellates, Isochrysis aff. galbana $(\mathrm{T})$ and Pavlova lutheri $(\mathrm{P})$, and two diatoms, Chaetoceros gracilis (C) or Skeletonema costatum (S), were tested as two ternary diets, namely PTC and PTS. PTC and PTS were compared with diets that also included $R$. salina (R). The addition of $R$. salina and the replacement of $C$. gracilis by $S$. costatum in the traditional hatchery diet seem to be two interesting alternatives for increasing the productivity of larval scallop culture and improving the metamorphosis rate. With these two diets, larval growth increased and metamorphosis was observed to occur more rapidly. Moreover, our results showed that the addition of $R$. salina significantly improved the overall condition of the larvae by promoting an increase in organic matter and total lipids. This accumulation of lipids during ontogeny seems to promote larvae to grow and to complete metamorphosis more rapidly than with the other diets. The level of polyunsaturated fatty acids in the algae could also at least partially explain the results obtained, since the PUFA level of $C$. gracilis was about half those of $S$. costatum and $R$. salina.
\end{abstract}

Keywords: Scallop; Nutrition; Metamorphosis; Energetic content; Algal fatty acids and sterols 


\section{Introduction}

52 The success of larval scallop culture and the recruitment of postlarvae in natural

53 populations depends on the accumulation of endogenous energy reserves to support larval

54 development and the metamorphic period. Metamorphosis consists of a series of events

55 involving major tissue reorganization to transit from a pelagic to a benthic way of life.

56 During this period, bivalve larvae are limited in their ability to feed on exogenous

57 particulates and rely on endogenous sources of energy. Neutral lipids and proteins

58 account for $>80 \%$ of the energy budget of metamorphosing bivalves; carbohydrates are

59 usually considered to be of minor importance (Holland \& Spencer 1973, Gallager et al.

60 1986, Whyte et al. 1992, Videla et al. 1998, García-Esquivel et al. 2001). However, these

61 findings do not rule out the potential of dietary carbohydrate in sustaining the energetic

62 needs of bivalve larvae during early ontogeny. Indeed, larvae of the scallop Patinopecten

63 yessoensis fed a diet rich in carbohydrate exhibited a higher nutritional condition

64 compared to those fed low carbohydrate diets (Whyte et al. 1989).

66 Microalgal polysaccharides are of nutritional significance since the digestive efficiency

67 of marine invertebrates depends on the type of polysaccharide ingested (Kristensen

68 1972). For instance, one of the main digestive enzymes of Pecten maximus larvae is

69 amylase, suggesting that starch is likely a preferred carbohydrate for this species.

70 Rhodomonas salina is known to be rich in starch. Shumway et al. (1985) showed that

71 ingested $R$. salina were absorbed in a majority of the bivalves they studied. Some

72 preliminary results showed that Pecten maximus larvae fed $R$. salina exhibited an

73 increase (by 1.8 times) in organic matter compared to those fed other diets (Robert et al. 
74 1994). Although the use of $R$. salina in a routine diet for different invertebrate species or

75 for juvenile bivalves has been previously reported (Enright et al. 1986, Brown et al. 1998,

76 McCausland 1999), the potential of $R$. salina to improve the growth rate and

77 metamorphosis in larval bivalves has not yet been investigated.

79 The objectives of the current research were (1) to optimize the classical ternary algal diets

80 used in P. maximus hatchery practices with the aim of maximizing larval survival and

81 growth and improving biochemical content before settlement, and (2) to evaluate the

82 addition of the cryptophyceae $R$. salina to the larval diet and to examine the related larval

83 performance during metamorphosis.

84

\section{$85 \quad$ Material and methods}

86 Animal maintenance and algal production

87 Adult scallops, Pecten maximus (about $150 \mathrm{~g}$ whole wet weight), were collected from the

88 Bay of Brest and kept in a flow-through seawater system at $15^{\circ} \mathrm{C}$ for 30 days and

89 continuously fed with a mixture of Isochrysis aff. galbana, Pavlova lutheri and

90 Chaetoceros gracilis at the Écloserie du Tinduff near Brest (Northern Brittany, France).

91 Scallops were induced to mass spawn by thermal shock following the method of

92 Gruffydd \& Beaumont (1970). Two days after fertilization, D-stage larvae were collected

93 on a $45 \mu \mathrm{m}$ square mesh screen. Five days after fertilization, scallops were transferred to

94 IFREMER's experimental hatchery located in Argenton, France. Nutritional experiments

95 consisting of 5 treatments were conducted in triplicate in 2-L glass beakers at an initial

96 density of 7 larvae $\cdot \mathrm{ml}^{-1}$. Larvae were reared in a temperature-controlled room at $19-20^{\circ} \mathrm{C}$ 
97 in 1- $\mu \mathrm{m}$ cartridge-filtered seawater at 34 ppt. Water was renewed every 2 or 3 days and

98 bacterial growth was limited by the addition of the antibiotic thiamphenicol at $8 \mathrm{mg} \cdot \mathrm{L}^{-1}$.

99 Larval cultures were maintained until metamorphosis (21 days post fertilization, dpf),

100 when survivors were harvested for biochemical analysis.

101

102 Microalgae were cultured in 18-L carboys with 1- $\mu \mathrm{m}$ filtered sterilized seawater enriched

103 with Conway medium and silicate $\left(40 \mathrm{mg} \cdot \mathrm{L}^{-1}\right)$ for diatoms. Algae were maintained at $104 \sim 20^{\circ} \mathrm{C}$ under continuous illumination from cool-white fluorescence lights at a light 105 intensity of 1500 lux and were mixed with aeration (air: $\left.\mathrm{CO}_{2}=98.5: 1.5 \%\right)$. Diatoms were 106 produced in batch and harvested in late exponential growth phase. Other species were 107 produced following a continuous method and harvested the day before utilization (Robert 108 et al. 1996a).

110 Experimental design

111 Two flagellates, Isochrysis aff. galbana (T) and Pavlova lutheri (P), and two diatoms,

112 Chaetoceros gracilis (C) and Skeletonema costatum (S), were tested as two standard 113 hatchery diets, namely PTC and PTS. These diets were compared to a new diet that 114 included $R$. salina (R), namely PTCR. Larvae were fed once a day with a daily ration of 115 one of three diets: 1:1:1 PTC or PTS at 45 cells $\mu \mathrm{l}^{-1}\left(\sim 1.1 \mathrm{ng} \cdot \mu \mathrm{l}^{-1}\right.$ dry weight, dw), or 116 1:1:1:1 PTCR at 60 cells $\cdot \mu \mathrm{l}^{-1}\left(\sim 3.3 \mathrm{ng} \cdot \mu \mathrm{l}^{-1} \mathrm{dw}\right)$. Two additional control diets were tested 117 to account for the higher biomass of the PTCR diet: PTC*C, which consisted of a daily 118 ration of 165 cells $\cdot \mu l^{-1}$ of PTC $\left(\sim 3.3 \mathrm{ng} \cdot \mu \mathrm{l}^{-1} \mathrm{dw}\right)$, and $\mathrm{PTC}^{*} \mathrm{G}$, which consisted of an 119 increasing daily ration of PTC, starting with 45 and increasing to 165 cells $\cdot \mu \mathrm{l}^{-1}(\sim 1.1$ to 
$120 \sim 3.3 \mathrm{ng} \cdot \mu \mathrm{l}^{-1} \mathrm{dw}$ from 5 to $21 \mathrm{dpf}$ ). The latter treatment was used to avoid an over

121 saturation of the larval culture with algae at the beginning of the experiment. Algal cells

122 were visually examined with a dissecting microscope at $40 \mathrm{x}$ and counted using a

123 haemocytometer cell before feeding scallop larvae.

\section{Growth and survival measurements}

126 Growth and survival were estimated every 2 or 3 days until metamorphosis (21 dpf) for

127 each experimental treatment ( $\mathrm{n}=3$ for each of the 5 diets). During the larval cycle, larvae 128 were collected on a $45-\mu \mathrm{m}$ mesh and mortality was assessed by counting a sample of 129 approximately 250 individuals. Mortality is expressed as a cumulative number of empty

130 shells based on the total number of shells. From hatching to the beginning of the 131 experiment (2 to $5 \mathrm{dpf}$ respectively), only ca. 10\% mortality occurred. Shell growth was 132 calculated on a sample of 50 to 90 larvae per treatment $(n=3 \times 5)$ using shell length 133 measurements (anterior-posterior distance) made with image analysis software (SXM for 134 MAC). Live larvae were recognized by the appearance of the double ring at the margin of 135 the shell, corresponding to a peripheral groove on which the dissoconch shell will be 136 attached (Doroudi et al. 1999). This criterion was used to assess the number of larvae that 137 began metamorphosis (Gerard et al. 1989).

139 Ash-free dry weight

140 The ash-free dry weight of larvae was estimated to evaluate their level of organic matter. 141 Larvae were ground, dried at $80^{\circ} \mathrm{C}$ for $24 \mathrm{~h}$ to obtain the dry weight, and then heated at 
$142450^{\circ} \mathrm{C}$ for $4 \mathrm{~h}$ to determine ash weight; a Mettler M3 microbalance was used. The organic

143 matter was calculated from the difference between the dry matter and the ash weight.

145 Biochemical analysis

146 Biochemical analyses of microalgae were carried out in triplicate for each separate

147 microalgal culture of $C$. gracilis, S. costatum and R. salina. Since the flagellates $I$.

148 galbana and P. lutheri were common to all three diets and their biochemical contents are

149 given in several publications (Delauney et al. 1993, Soudant et al. 1996, 2000, Brown et

150 al. 1997), they were not characterized. Microalgal cultures (5 to $15 \mathrm{ml}$ ) were filtered onto

$15125 \mathrm{~mm}$ Whatman $\mathrm{GF} / \mathrm{F}$ filters pre-combusted at $450^{\circ} \mathrm{C}$. The filters were placed in $15 \mathrm{ml}$

152 glass tubes containing $6 \mathrm{ml}$ of a mixture of chloroform and methanol $(2: 1, \mathrm{v}: \mathrm{v})$ with

$1530.01 \%$ butylated hydroxytoluene (BHT) as an antioxidant, closed under nitrogen, shaken,

154 and frozen at $-20^{\circ} \mathrm{C}$ for lipid extraction following the Folch procedure (Folch et al. 1957).

155 Multiple procedure blanks were prepared. Prior to lipid extraction, samples were

156 sonicated for $10 \mathrm{~min}$ in chloroform-methanol $(2: 1 ; \mathrm{v} / \mathrm{v})$ using a sonicating bath at $5^{\circ} \mathrm{C}$.

157 Lipid extracts were evaporated to dryness and recovered with three $500-\mu 1$ washings of

158 98:2 chloroform:methanol.

159

160 Total lipids were transesterified under nitrogen using $\mathrm{BF}_{3} / \mathrm{CH}_{3} \mathrm{OH}$ for 10 minutes at

$161100^{\circ} \mathrm{C}$. Fatty acid methyl esters (FAME) were analyzed using a gas chromatograph

162 equipped with an on-column injector, a DB-Wax $(30 \mathrm{~m} \times 0.25 \mathrm{~mm} ; 0.25 \mu \mathrm{m}$ film

163 thickness) capillary column and a flame ionization detector. Hydrogen was used as the 
164 gas carrier. Fatty acids were identified by comparing their retention time with standards

165 and quantified with tricosanoic acid (23:0) as an internal standard.

166

167 Sterols were obtained from the neutral lipid fraction as previously described (Marty et al.

168 1992). Neutral lipids were transesterified using sodium methoxyde (MeONa) at ambient

169 temperature for 90 minutes. This method allows the protection of certain phytosterols

170 such as 24-methylene cholesterol. Esterified sterols were analyzed using a gas

171 chromatograph equipped with an on-column injector and a Restek Rtx65 fused silica

172 capillary column (15 $\mathrm{m} \times 0.25 \mathrm{~mm} ; 0.25 \mu \mathrm{m}$ film thickness). Hydrogen was used as the

173 gas carrier. Esterified sterol fractions were identified by comparing their retention times

174 with standards and were quantified with cholestane as an internal standard.

175

176 One sample of 21-day-old larvae (ca. 6000-11000 ind.) was harvested from each tank

177 onto $25 \mathrm{~mm}$ Whatman $\mathrm{GF} / \mathrm{F}$ filters pre-combusted at $450^{\circ} \mathrm{C}$. Lipids from scallop larvae

178 were extracted for total lipid quantification as previously described for micoalgae.

179 Subsamples were used for colorimetric determinations of proteins (Lowry et al. 1951)

180 and carbohydrates (Dubois et al. 1956). Larvae were rinsed with $10 \mathrm{ml}$ of $37 \%$

181 ammonium formate then homogenized in $1 \mathrm{ml}$ of nanopure water before analysis.

182 Colorimetric assays were performed on a Uvikon ${ }^{\circledR}$ spectrophotometer.

183

184 Statistical analysis

185 Survivorship patterns were compared using the Life Test procedure from SAS 8.02 (SAS

186 Institute Inc. 1999-2001). Multiple analyses of variance (MANOVAs) were conducted to 
187 determine differences in fatty acid and sterol profiles among algal species. MANOVAs

188 on the fatty acid profiles considered total fatty acids (TFA), monosaturated fatty acids

189 (MUFA), polyunsaturated fatty acids (PUFA), EPA, DHA, and AA as dependent

190 variables A two-way analysis of variance (ANOVA) was conducted to determine

191 differences in shell length and occurrence of double rings as a function of diet and day. A

192 one-way ANOVA was performed to determine differences in organic matter as a function

193 of dietary treatment. A one-way MANOVA was performed to determine differences in

194 absolute (ng.larva ${ }^{-1}$ ) and relative (mass \% of OM) concentrations of protein, lipid and

195 carbohydrate in 21-day-old scallops. Where differences were detected, least-square

196 differences (LSD) multiple comparison tests were used to determine which means were

197 significantly different. Residuals were screened for normality using the expected normal

198 probability plot and further tested using the Kolmogorov-Smirnov test. Homogeneity of

199 variance-covariance matrices was tested using the Levene test. Percentages were arcsine

200 square-root transformed to achieve homogeneity of variances. Variance analyses were

201 carried out using SPSS 13.0 for Windows (Chicago, IL). The significance value for all 202 analyses was set at $P<0.05$.

\section{Results}

\section{Microalgal lipid composition}

206 Total fatty acids (TFA, in pg.cell ${ }^{-1}$ ) in $R$. salina were 2.2 and 2.5 times higher than those

207 observed in $C$. gracilis and $S$. costatum respectively (Table 1). The diatom C. gracilis

208 was lower in polyunsaturated fatty acids (PUFA) compared to $S$. costatum (by 1.9 times)

209 and $R$. salina (by 2.2 times). Indeed, C. gracilis was characterized by elevated levels of 
210 saturated (SFA) and monounsaturated (MUFA) fatty acids, with these two fatty acid

211 classes constituting $\sim 72 \%$ of the TFA. The long chain PUFAs 20:5n-3 (EPA), 22:6n-3

212 (DHA) and 20:4n-6 (AA) collectively contributed 48.9, 36.8 and $24.2 \%$ of the total

213 PUFA found in $C$. gracilis, $S$. costatum and $R$. salina respectively. The major long chain

214 PUFA in C. gracilis was EPA while AA and DHA remained low. S. costatum was

215 characterized by a high level of EPA, an intermediate level of DHA and a low level of

216 AA. Finally, $R$. salina exhibited the lowest level of EPA, an intermediate level of DHA

217 and the highest level of AA. As a consequence, the DHA/EPA ratio varied from 0.11 in

218 C. gracilis and 0.38 in $S$. costatum to 0.75 in $R$. salina.

220 Total sterol concentration (in fg.cell ${ }^{-1}$ ) in $R$. salina was $\sim 2$ times lower than those

221 observed in S. costatum and C. gracilis (Table 2). High sterol concentrations were 222 characteristic of the microalgal species. For instance, $C$. gracilis had a high level of 223 cholesterol and fucosterol and low levels of 24-methylene cholesterol, iso-fucosterol and

224 brassicasterol. In contrast, S. costatum exhibited a high level of 24-methylene cholesterol, 225 intermediate levels of campesterol and cholesterol, and low levels of $\beta$-sitosterol and 226 desmosterol. Finally, R. salina showed two major sterols, brassicasterol ( $>90 \%$ of total 227 sterol) and cholesterol.

229 Scallop performance

230 Diet and day showed an interaction in their effect on the shell length of scallop larvae

231 (Table 3 and Fig. 1). Larvae offered PTS and PTCR exhibited greater shell lengths than 232 those fed all other diets $(P<0.001)$, and the PTS and PTCR diets showed similar growth 
$233(P=0.081)$. These results are reflected by the growth rates, with values of $7.29 \pm 0.25$ and

$2346.94 \pm 0.33 \mu \mathrm{m} \mathrm{day}^{-1}$ for PTS and PTCR compared to $5.04 \pm 0.53,4.69 \pm 0.43$ and $3.88 \pm 0.16$

$235 \mu \mathrm{m} \mathrm{day}^{-1}$ for PTC, PTCC and PTCG. No dietary effect was detected on scallop survival

236 (Lifetest procedure, $P=0.966$ ). At the end of the experiment, cumulative survival varied

237 between $\sim 70$ to $80 \%$ (Fig. 2). The occurrence of double rings varied as a function of day

238 and diet (Table 3 and Fig. 3). The first double rings appeared at around $15 \mathrm{dpf}$ in larvae

239 fed the PTCR diet. The highest percentage of double rings was recorded at $17 \mathrm{dpf}$ for the

240 PTCR diet compared to the PTS diet $(P<0.05)$; larvae from the PTC diet had no double

241 rings at all. At 19 and 21 dpf, scallops fed PTCR and PTS were at a similar stage of

242 development $(P=0.981)$ and showed a higher level $(\sim 5 \times)$ of double rings than scallops fed

243 the other diets $(P<0.003)$. Occurrences of double rings were similar between larvae fed

244 PTC, $\mathrm{PTC} * \mathrm{G}$ and $\mathrm{PTC} * \mathrm{C}(P=0.862)$. Finally, dissoconchs were first observed after 19

245 dpf in cultures fed PTCR and only after $21 \mathrm{dpf}$ for those fed PTS. Cultures fed other diets

246 did not exhibit any dissoconchs during the experiment. Therefore, PTCR and PTS

247 promoted higher growth rates and better metamorphic yields than the other diets tested.

249 Biochemical content

250 The ash-free dry weight of $21 \mathrm{dpf}$ larvae varied between $\sim 350$ and $650 \mathrm{ng} \cdot$ larva $^{-1}$,

251 depending on the dietary treatment $(P=0.002)$. Indeed, the top performing larvae fed

252 PTCR and PTS exhibited ash-free dry weights nearly twice as high as larvae fed all other

253 dietary treatments $(P<0.011$; Fig. 4). The absolute contents (amount per larva) of lipids

254 and proteins in $21 \mathrm{dpf}$ larvae were significantly influenced by the diet while carbohydrate

255 content was not (Table 4). Indeed, larvae fed the top-performing PTCR and PTS diets 
256 showed an increase $(\sim 1.8 \times)$ in their lipid and protein contents compared to those fed other

257 diets (Table 5, $P<0.001$ ). Larvae fed PTCR had higher lipid levels than larvae fed PTS

$258(P=0.003)$; both these diets had lipid levels that were significantly higher than other diets

$259(P<0.010)$. Larvae fed PTCR and PTS had similar proteins levels $(P=0.566)$ that were

260 again significantly higher than other diets. Relative concentrations of lipids, proteins and

261 carbohydrates were $\sim 32,63$ and $5 \%$ of OM, respectively (Fig. 5). Therefore, differences

262 in the ash-free dry weight were mainly attributable to lipids and proteins since

263 carbohydrates were scarce in 21 dpf larvae.

264

265 Discussion

266 Based on growth rate, on the biochemical content of larvae and on metamorphic yield

267 (estimated by the double ring rate), our results showed that PTCR and PTS were the best 268 performing diets, followed by $\mathrm{PTC}$ and then $\mathrm{PTC}^{*} \mathrm{C}$ and $\mathrm{PTC} * \mathrm{G}$, for the culture of 269 scallop Pecten maximus larvae. Larvae fed PTS or PTCR showed higher organic matter 270 and total lipid and protein contents than larvae fed PTC. Moreover, larvae fed the PTCR 271 diet had a higher total lipid and organic matter content and underwent metamorphosis 272 earlier compared to larvae fed the PTS diet. Our results show that the addition of $R$. 273 salina significantly improved the condition of the larvae by promoting the enrichment of 274 organic matter through proteins and total lipids. The starch content in the $R$. salina cells 275 ( $\sim 40 \%$ of total carbohydrates; present study) seemed beneficial to $P$. maximus larvae 276 compared to others algal species; carbohydrate levels in diatoms (C. gracilis and $S$. 277 costatum) and prymnesiophytes (I. galbana and P. lutheri) are generally under 15\% 278 (Brown et al. 1997). These carbohydrates could provide an energy source for metabolic 
279 demand during larval development. It may also be converted to and accumulated as

280 lipids. This high level of organic matter in the form of proteins and lipids stored in

281 organisms with shells of about the same size at metamorphosis seems to promote larvae

282 to complete metamorphosis more rapidly. The biomass provided by the PTCR diet was

283 approximately three times higher than that of the PTC diet (3.3 compared to $1.1 \mathrm{ng} \cdot \mathrm{l}^{-1}$

$284 \mathrm{dw}$ ) and was amplified by the larger volume of $R$. salina, which has cell sizes of 11.9 to

$28512.8 \mu \mathrm{m}$ in diameter (Schiopu et al. 2006). In addition to the extra biomass provided by 286 the addition of $R$. salina to the traditional larvae diet composed of Pavlova lutheri,

287 Isochrysis aff. galbana and Chaetoceros gracilis, we observed a significant effect of $R$.

288 salina on larval scallop culture. Larvae fed the adjusted PTC diet (on the basis of algal

289 dry weight), that is, with a continuous or gradual addition of algae (PTC*C and $\left.\mathrm{PTC}^{*} \mathrm{G}\right)$

290 to obtain biomasses similar to the PTCR diet, did not show superior growth or higher

291 biochemical content than larvae fed the PTC diet. In fact, lower growth was observed

292 with these diets even though there was a higher availability of organic matter. These

293 results suggest a negative effect of a high concentration of small algal cells on the feeding

294 activity of scallop larvae, as has been reported for mussel larvae (Sprung 1984, 1989),

295 probably due to the saturation of the particulate filtration system. Lu and Blake (1996)

296 observed that I. galbana cell concentrations higher than 40 cells $\mu \mathrm{l}^{-1}$ saturated the

297 ingestion rate of larval bay scallops, Argopecten irradians. In our experiment, we did not

298 evaluate whether the 165 cells $\cdot \mu l^{-1}$ of the $\mathrm{PTC} * \mathrm{C}$ and $\mathrm{PTC} * \mathrm{G}$ diets decreased the 299 ingestion rate of larvae, but these high algal densities did not increase scallop larva 300 mortality. The increased feed concentrations may cause water quality problems due to 301 bacteria proliferation. Nevertheless, the use of antibiotics to ensure the success of $P$. 
302 maximus larval culture seems to limit this problem, as no more mortality was observed in

303 these treatments. The use of antibiotics at a concentration of $8 \mathrm{mg} \cdot \mathrm{L}^{-1}$ has been

304 demonstrated to be beneficial for the survival of scallop larvae with no impact on the 305 growth rate (Nicolas et al. 1996, Robert et al. 1996). The quantitative advantage for larval

306 growth with $R$. salina in the algal diet may have resulted from the high level of digestible

307 organic matter available. The results suggest a good ingestion and retention ability as

308 well as efficient assimilation of this large microalgae by the P. maximus scallop larvae, as

309 has already been demonstrated for adult sea scallops, Placopecten magellanicus

310 (Shumway et al. 1985).

311

312 Qualitative differences between diets can contribute to performance. The PTS diet, which

313 provided less algal dry weight than the PTCR diet, showed better growth than the PTC

314 diet from day 12 until the end of the experiment and a growth pattern similar to PTCR at

315 the end of the larval cycle (between 17 and $21 \mathrm{dpf}$ ). The PUFA levels in our diets could 316 explain at least partially the growth and metamorphic results. Indeed, the PUFA level of

317 C. gracilis in the PTC diet was half that of $S$. costatum in PTS and also lower, but to a

318 lesser extent, than $R$. salina in the PTCR diet. Lipids, and more particularly the essential

319 polyunsaturated fatty acids (PUFA), are generally considered to be the most important

320 constituent of the algal diet for bivalve larvae (Whyte et al. 1989, Delaunay et al. 1993,

321 Soudant et al. 1998, Nevejan et al. 2003, Pernet \& Tremblay 2004).

322

323 However, the success of the PTS diet is not in accordance with a previous study, where 324 poor ingestion of $S$. costatum in a PTS diet was observed and related to lower growth 
325 compared to P. maximus larvae fed with Chaetoceros calcitrans (Soudant et al. 1998).

326 According to published results on the biochemical compositions of microalgae species,

327 the polyunsaturated fatty acid profile of $S$. costatum is similar to that of $C$. gracilis,

328 showing a predominance of EPA with low levels of DHA, very low levels of AA and low

329 variability between strains (Brown et al. 1989, Volkman et al. 1989, Dunstan et al. 1993).

330 However, in our experiment, the DHA percentage composition was five-fold higher in $S$.

331 costatum compared to $C$. gracilis. It has been previously observed that $P$. maximus larvae

332 fed on diatoms only had a good growth rate but failed at metamorphosis (Delaunay et al.

333 1993). This was attributed to a high DHA requirement during this period of active

334 changes in morphology and membrane building, as an EPA/DHA ratio of about 2 was

335 highly controlled in polar lipids of Pecten maximus larvae. A higher percentage of DHA

336 in the PTS diet would meet such a requirement better than the PTC diet and would

337 improve the growth and success of $P$. maximus larval metamorphosis; survival was

338 similar with other diets, as has been observed in Crassostrea gigas larvae (Volkman et al.

339 1989) and spat (Thompson \& Harrisson 1992). These high levels of DHA in S. costatum

340 compared to values reported in the literature would reflect culture conditions. Many

341 studies indicate that diatoms submitted to nutritive stress will significantly increase their

342 lipid levels (Dunstan 1993, Von Elert 2002, Pernet et al. 2003). However, high DHA

343 levels may also be associated with a specific strain, which seems to be the case in our

344 study. The good performance obtained when PTC was supplemented with $R$. salina in the

345 PTCR diet could also result from a higher DHA/EPA ratio compared to the diet 346 consisting of $C$. gracilis alone. 
348 We observed that saturated fatty acids (SFA) seemed not to be a predominant factor

349 influencing the growth of $P$. maximus larvae: the SFA in $C$. gracilis, included in the PTC

350 diet, were twice as high as those from $S$. costatum. SFA provide more energy via $\beta$ -

351 oxidation than PUFA, and our results contradict an earlier study showing a superiority of

352 diets containing higher amounts of SFA for Placopecten magellanicus and Crassostrea

353 gigas larvae (Langdon \& Waldock 1981). It is possible that the SFA effect can be

354 detected when other limiting factors are optimized.

356 The sterol composition of microalgae could be important in determining the nutritional

357 value for bivalves (Wikfors et al. 1996). In our study, we observed that the total amount

358 of sterol was twice as high in $C$. gracilis and $S$. costatum compared to R. salina.

359 Furthermore, the cholesterol concentration in $C$. gracilis was more than twice that in $S$.

360 costatum and 5 times higher than concentrations in $R$. salina. Thus, in the diets studied,

361 the level of sterols and more specifically cholesterol seemed not to be limiting for larval

362 growth. Nevertheless, we observed that $S$. costatum sterol is composed mainly of 24-

363 methylene cholesterol (nearly $42 \%$ ) and that $R$. salina is very rich in brassicasterol (90\%),

364 two sterol classes used by oyster spat for the bioconversion of cholesterol (Soudant et al.

365 2000). Marine bivalves contain complex mixtures of $\mathrm{C}_{26}$ to $\mathrm{C}_{30}$ sterols (cholesterol $=$

$366 \mathrm{C}_{27}$ ), with each molecular species being characterized by a planar ring system with a $3 \beta$ -

367 hydroxyl group and a side chain of varying length. Furthermore, bivalves have a

368 negligible capacity for the biosynthesis or conversion of sterols, although they are

369 capable of selectively incorporating certain sterols (Soudant et al. 1996, Knauer et al. 
370 1999). In Pecten maximus, the preferential incorporation of cholesterol over other sterols

371 has been previously observed (Soudant et al. 1998).

372

373 In conclusion, our results suggest that a more efficient diet to improve larval growth of $P$.

374 maximus and to attain metamorphosis more rapidly would be obtained by the addition of

$375 R$. salina to a traditional hatchery diet composed of I. galbana, P. lutheri and C. gracilis.

376 We also observed that the replacement of $C$. gracilis by $S$. costatum in a diet including $I$.

377 galbana and $P$. lutheri seemed to improve larval growth of $P$. maximus. However, this

378 last result seems to be associated with a specific Skeletonema costatum strain and

379 particular culture conditions. Nevertheless, further investigations are being undertaken to

380 better understand the effect of the addition $R$. salina on the kinetics of fatty acids, lipid

381 classes, proteins and carbohydrates during larval development and for metamorphosis

382 success and spat competency.

383

384 Acknowledgements

385 The authors would like to thank Tinduff technicians Alain Le Gall, Anne Doen and Régis

386 Lasbleiz for providing scallop larvae. The authors are also grateful to Mathieu Cusson

387 and Andréane Bastien for help with statistical analyses and Laure Devine for text 388 revision.

\section{$390 \quad$ References}

391 Brown MR, Jeffrey SW, Garland CD (1989) Nutritional aspects of microalgae used in 392 aquaculture: A literature review. Report 205, CSIRO Marine Laboratories 
393 Brown MR, Jeffrey SW, Volkman JK, Dunstan GA (1997) Nutritional properties of

394 microalgae for mariculture. Aquaculture 15:315-331

395 Brown MR, McCausland MA, Kowalski K (1998) The nutritional value of four

396 Australian microalgal strains fed to Pacific oyster Crassostrea gigas spat. $397 \quad$ Aquaculture 165:281-293

398 Delaunay F, Marty Y, Moal J, Samain J-F (1993) The effect of monospecific algal diets

399 on growth and fatty acid composition of Pecten maximus (L.) larvae. J. Exp. Mar.

$400 \quad$ Biol. Ecol. 173:163-179

401 Doroudi MS, Southgate PC, Mayer RJ (1999) Growth and survival of blackslip pearl 402 oyster larvae fed different densities of microalgae. Aquacul. Int. 7:179-187

403 Dubois M, Gillies KA, Hamilton JK, Rebers PA, Smith F (1956) Colorimetric method for 404 the determination of carbohydrates and related substances. Anal. Chem. 28:350$405 \quad 356$

406 Dunstan G (1993) Changes in the lipid composition and maximization of the 407 polyunsaturated fatty acid content of three microalgae grown in mass culture. J. $408 \quad$ Appl. Phycol. 5:71-83

409 Dunstan GA, Volkman JK, Barrett SM, Leroi J-M, Jeffrey SW (1993) Essential 410 polyunsaturated fatty acids from 14 species of diatom (Bacillariophyceae). $411 \quad$ Phytochem. 35:155-161

412 Enright CT, Newkirk GF, Craigie JS, Castell JD (1986) Evaluation of phytoplankton as 413 diets for juvenile Ostrea edulis L. J. Exp. Mar. Biol. Ecol. 96:1-13

414 Folch J, Lees M, Sloane-Stanley GH (1957) A simple method for the isolation and 415 purification of total lipids from animal tissues. J. Biol. Chem. 226:497 
416 Gallager SM, Mann R, Sasaki GC (1986) Lipid as an index of growth and viability in

417 three species of bivalve larvae. Aquaculture 56:81-103

418 Garcia-Esquivel Z, Bricelj VM, Gonzalez-Gomez MA (2001) Physiological basis for 419 energy demands and early postlarval mortality in the Pacific oyster, Crassostrea 420 gigas. J. Exp. Mar. Biol. Ecol. 263:77-103

421 Gerard A, Salaun M, Tritar S (1989) Critères de compétences des larves à la 422 métamorphose chez Pecten maximus. Haliotis 19:373-380

423 Gruffydd LD, Beaumont AR (1970) Determination of the optimum concentration of eggs 424 and spermatozoa for the production of normal larvae in Pecten maximus. Helgol. Wiss. Meeresunters 20: 486-497

426 Holland DL, Spencer BE (1973) Biochemical changes in fed and starved oysters, Ostrea 427 edulis L., during larval development, metamorphisis and early spat growth. J. $428 \quad$ Mar. Biol. Ass. U.K. 53:287-298

429 Knauer J, Barrett SM, Volkman JK, Southgate PC (1999) Assimilation of dietary 430 phytosterols by Pacific oyster Crassostrea gigas spat. Aquacul. Nut. 5:257-267

431 Kristensen JH (1972) Carbohydrases of some marine invertebrates with notes on their 432 food and on the natural occurrence of the carbohydrates studied. Mar. Biol. $433 \quad 14: 130-142$

434 Langdon CJ, Waldock MI (1981) The effect of algal and artificial diets on the growth and 435 fatty acid compostion of Crassostrea gigas spat. J. Mar. Biol. Ass. U.K. 61:431$436 \quad 440$

437 Lowry OH, Rosebrough NJ, Farr AL, Randall RJ (1951) Protein measurement with the $438 \quad$ Folin phenol reagent. J. Biol. Chem. 193:265-275 
439 Lu YT, Blake NJ (1996) Optimum concentrations of Isochrysis galbana for growth of

$440 \quad$ larval and juvenile bay scallops, Argopecten irradians concentricus (Say). J.

$441 \quad$ Shellfish Res. 15:635-643

442 Marty Y, Delaunay F, Moal J, Samain J-F (1992) Changes in the fatty acid composition

443 of Pecten maximus (L.) during larval development. J. Exp. Mar. Biol. Ecol.

$444 \quad 163: 221-234$

445 McCausland MA, Brown MR, Barrett SM, Diemar JA, Heasman MP (1999) Evaluation

446 of live microalgae and microalgal pastes as supplementary food for juvenile

447 Pacific oysters (Crassostrea gigas). Aquaculture 174:323-342

448 Nevejan N, Saez I, Gajardo G, Sorgeloos P (2003) Energy vs. essential fatty acids: what

449 do scallop larvae (Argopecten purpuratus) need most? Comp. Biochem. Physiol.

$450 \quad 134 \mathrm{~B}: 599-613$

451 Nicolas J-L, Corre S, Gauthier G, Robert R, Ansquer D (1996) Bacterial problems 452 associated with scallop Pecten maximus larval culture. Dis. Aquat. Org. 27:67-76

453 Pernet F, Tremblay R (2004) Effect of varying levels of dietary essential fatty acid during 454 early ontogeny of the sea scallop Placopecten magellanicus. J. Exp. Mar. Biol. $455 \quad$ Ecol. $310: 73-86$

456 Pernet F, Tremblay R, Demers E, Roussy M (2003) Variation of lipid class and fatty acid 457 composition of Chaetoceros muelleri and Isochrysis sp. grown in a semicontinuous system. Aquaculture 221:393-406

459 Robert R, Moal J, Campillo M-J, Daniel JY (1994) The food value of starch rich 460 flagellates for Pecten maximus (Linné) larvae. Preliminary results. Haliotis 461 23:169-171 
462 Robert R, Moal J, Miner P, Quéré C, Connan JP, Daniel JY, Le Coz JR, Samain JF, 463 Mazuret M (1996a) Microalgae biomass from photobioreactor as food for fish and 464 shellfish larvae (MANTA). European Community Program, final report. A1R1$465 \quad$ CT92-0286, pp. 68-91

466 Robert R, Miner P, Nicolas J-L (1996b) Mortality control of scallop larvae in the 467 hatchery. Aquacul. Inter. 4:305-313

468 Schiopu D, George SB, Castell J (2006) Ingestion rates and dietary lipids affect growth 469 and fatty acid composition of Dendraster excentricus larvae. J. Exp. Mar. Biol. $470 \quad$ Ecol. $328: 47-75$

471 Shumway SE, Cucci TL, Newell RIE, Yentsch CM (1985) Particle selection, ingestion, 472 and absorption in filter-feeding bivalves. J. Exp. Mar. Biol. Ecol. 91:77-92

473 Soudant P, Marty Y, Moal J, Masski H, Samain JF (1998) Fatty acid composition of 474 polar lipid classes during larval development of scallop Pecten maximus (L.). 475 Comp. Biochem. Physiol. 121 A:279-288

476 Soudant P, Marty Y, Moal J, Robert R, Quere C, Le Coz JR, Samain JF (1996) Effect of 477 food fatty acid and sterol quality on Pecten maximus gonad composition and 478 reproduction process. Aquaculture 143:361-378

479 Soudant P, Sanles MV, Quere C, Le Coz JR, Marty Y, Moal J, Samain JF, Sorgeloos P 480 (2000) The use of lipid emulsions for sterol supplementation of spat of the Pacific oyster, Crassostrea gigas. Aquaculture 184:315-326

482 Sprung M (1984) Physiological energetics of mussel larvae (Mytilus edulis). II. Food 483 uptake. Mar. Ecol. Prog. Ser. 17:295-305 
484 Sprung M (1989) Field and laboratory observations of Dreissena polymorpha larvae: abundance, growth, mortality and food demands. Arch. Hydrobiol. 115:537-561

Thompson PA, Harrisson PJ (1992) Effects of monospecific algal diets of varying biochemical composition on the growth and survival of Pacific oyster (Crassostrea gigas) larvae. Mar. Biol. 113:645-654

Von Elert E (2002) Determination of limiting polyunsaturated fatty acids in Daphnia galeata using a new method to enrich food algae with single fatty acids. Limnol. Oceanogr. 47:1764-1773

Videla JA, Chaparro OR, Thompson RJ, Concha II (1998) Role of biochemical energy reserves in the metamorphosis and early juvenile development of the oyster Ostrea chilensis. Mar. Biol. 132:635-640

Volkman JK, Jeffrey SW, Nichols PD, Rogers GI, Garland CD (1989) Fatty acid and lipid composition of 10 species of microalgae used in mariculture. J. Exp. Mar. Biol. Ecol. 128:219-240

Wikfors GH, Patterson GW, Ghosh P, Lewin RA, Smith BC, Alix JH (1996) Growth of post-set oysters, Crassostrea virginica, on high-lipid strains of algal flagellates Tetraselmis spp. Aquaculture 143:411-419

504 Whyte JNC, Bourne N, Hodgson CA (1989) Influence of algal diets on biochemical 505 composition and energy reserves in Patinopecten yessoensis (Jay) larvae. Aquaculture 1989:333-347 
507 Table 1. Fatty acid composition of the diatoms Chaetoceros gracilis (CHGRA) and 508 Skeletonema costatum (SKEL) and the flagellate Rhodomonas salina (RHODO), 509 expressed as \% of total fatty acids. Also shown are the n-3/n-6, DHA/EPA and EPA/AA 510 ratios as well as the total fatty acids (TFA; pg.cell $^{-1}$ ).

\begin{tabular}{|c|c|c|c|}
\hline Fatty acid & CHGRA & $\overline{\text { SKEL }}$ & RHODO \\
\hline $14: 0$ & 16.38 & 14.39 & 15.48 \\
\hline $16: 0$ & 24.85 & 6.84 & 20.17 \\
\hline 18:0 & 3.77 & 0.93 & 1.46 \\
\hline$\Sigma$ SFA & 45.45 & 22.27 & 37.11 \\
\hline $16: 1 n-9$ & - & 0.08 & - \\
\hline $16: 1 n-7$ & 25.31 & 13.94 & 1.11 \\
\hline $16: 1 n-13 t$ & 0.61 & 1.14 & 0.52 \\
\hline $18: 1 n-9$ & 0.24 & 1.14 & 11.79 \\
\hline $18: 1 n-7$ & 0.96 & 1.14 & 1.68 \\
\hline$\Sigma$ MUFA & 27.13 & 18.43 & 15.61 \\
\hline $16: 2 n-7$ & 2.54 & 1.55 & - \\
\hline $16: 2 n-4$ & 1.93 & 2.53 & - \\
\hline $16: 3 n-4$ & 5.59 & 20.55 & - \\
\hline $18: 2 n-6$ & 0.18 & 2.46 & 15.01 \\
\hline $18: 3 n-6$ & 0.46 & 0.07 & 3.27 \\
\hline $18: 3 n-3$ & - & 0.99 & 7.98 \\
\hline $18: 4 n-3$ & 0.72 & 3.75 & 7.80 \\
\hline $20: 4 n-6(A A)$ & 0.1 & 0.27 & 2.98 \\
\hline 20:5n-3 (EPA) & 10.71 & 13.80 & 4.78 \\
\hline 22:6n-3 (DHA) & 1.14 & 5.30 & 3.58 \\
\hline$\Sigma$ PUFA & 24.31 & 52.64 & 46.77 \\
\hline$\Sigma \mathrm{n}-\mathbf{3}$ & 13.11 & 24.57 & 24.68 \\
\hline$\Sigma \mathrm{n}-6$ & 1.09 & 3.35 & 22.06 \\
\hline$n-3 / n-6$ & 12.03 & 7.33 & 1.12 \\
\hline DHA/EPA & 0.11 & 0.38 & 0.75 \\
\hline $\mathrm{EPA} / \mathrm{AA}$ & 107.1 & 51.1 & 1.60 \\
\hline TFA $\left(\right.$ pg.cell $\left.{ }^{-1}\right)$ & 5.17 & 4.53 & 11.34 \\
\hline
\end{tabular}


511 Table 2. Sterol compositions of the diatoms Chaetoceros gracilis (CHGRA) and

512 Skeletonema costatum (SKEL) and the flagellate Rhodomonas salina (RHODO),

513 expressed as \% of total sterols.

514

\begin{tabular}{lccc}
\hline Sterol & CHGRA & SKEL & RHODO \\
\hline Cholesterol & 47.21 & 20.04 & 9.71 \\
Brassicasterol & 1.31 & - & 90.29 \\
Desmosterol & - & 4.04 & - \\
Campesterol & - & 28.04 & - \\
$24-$ methylene cholesterol & 8.40 & 41.56 & - \\
Stigmasterol & - & - & - \\
$\beta$-sitosterol & - & 6.33 & - \\
Fucosterol & 38.18 & - & - \\
Iso-fucosterol & 4.90 & - & - \\
Total sterols (fg.cell ${ }^{-1}$ ) & 107.68 & 98.22 & 55.68 \\
\hline
\end{tabular}


516 Table 3. Summary of ANOVAs showing the effect of day and diet on (a) shell length and

517 (b) occurrence of double rings.

518

\begin{tabular}{lllll}
\hline Source of variation & df & MS & $F$-value & $p$ \\
\hline
\end{tabular}

(a) Shell length

$\begin{array}{lrrrr}\text { Day } & 6 & 1.1 \times 10^{4} & 446<0.001 \\ \text { Diet } & 4 & 2.5 \times 10^{3} & 99<0.001 \\ \text { Day*Diet } & 24 & 256 & 10<0.001 \\ \text { Error } & 70 & 25 & & \\ \text { Corrected total } & 104 & & & \end{array}$

(b) Double ring*

$\begin{array}{lrrrr}\text { Day } & 1 & 0.478 & 239 & <0.001 \\ \text { Diet } & 4 & 0.553 & 277 & <0.001 \\ \text { Day*Diet } & 4 & 1.6 \times 10^{-3} & 0.818 & 0.529 \\ \text { Error } & 20 & 1.9 \times 10^{-3} & & \\ \text { Corrected total } & 29 & & & \end{array}$

$519 *$ Arcsinus transformation for double ring occurrence was applied to normalize the data. 520 
521 Table 4. Summary of MANOVAs showing the effect of diets on lipids, proteins and 522 carbohydrates at (a) absolute (ng larva ${ }^{-1}$ ) and (b) relative (\%) values.

523

\begin{tabular}{lllll}
\hline Diet & df & MS & $F$-value & $p$ \\
\hline
\end{tabular}

(a) Absolute concentration*

$\begin{array}{lrlrr}\text { Lipids } & 4 & 7.03 \times 10^{-2} & 44.1<0.001 \\ \text { Proteins } & 4 & 4.84 \times 10^{-2} & 19.3<0.001 \\ \text { Carbohydrates } & 4 & 1.35 \times 10^{-2} & 1.8 & 0.198 \\ \text { Error lipids } & 10 & 1.59 \times 10^{-3} & & \\ \text { Error proteins } & 10 & 2.51 \times 10^{-3} & & \\ \text { Error carbohydrates } & 10 & 7.36 \times 10^{-3} & & \\ \text { Corrected total lipids } & 14 & & & \\ \text { Corrected total proteins } & 14 & & & \end{array}$

(b) Relative concentration*

$\begin{array}{lrlrl}\text { Lipids } & 4 & 1.86 \times 10^{-3} & 7.3 & 0.005 \\ \text { Proteins } & 4 & 1.84 \times 10^{-3} & 5.5 & 0.013 \\ \text { Carbohydrates } & 4 & 2.88 \times 10^{-3} & 3.9 & 0.057 \\ \text { Error lipids } & 10 & 2.52 \times 10^{-4} & & \\ \text { Error proteins } & 10 & 3.36 \times 10^{-4} & & \\ \text { Error carbohydrates } & 10 & 7.39 \times 10^{-4} & & \\ \text { Corrected total lipids } & 14 & & \\ \text { Corrected total proteins } & 14 & & \\ \text { Corrected total carbohydrates } & 14 & & \end{array}$

$524 *$ Logarithmic and arcsinus transformations, respectively, were applied on absolute (ng 525 larva $^{-1}$ ) and relative (\%) values to normalize the data. 
526 Table 5. The biochemical content of larvae (ng larva $\left.{ }^{-1}\right)$ at $21 \mathrm{dpf}$ fed with $\mathrm{PTC}, \mathrm{PTC} \mathrm{G}^{*}$, 527 PTC*C, PTCR and PTS (mean \pm SD). See text for diet abbreviations.

528

\begin{tabular}{lccccc}
\hline & PTC & PTC*G & PTC*C & PTCR & PTS \\
\hline Lipid & $78.5 \pm 7.6^{\mathrm{a}}$ & $67.2 \pm 2.3^{\mathrm{a}}$ & $59.6 \pm 6.6^{\mathrm{a}}$ & $141.5 \pm 13.0^{\mathrm{b}}$ & $106.4 \pm 10.5^{\mathrm{c}}$ \\
Protein & $135.6 \pm 10.8^{\mathrm{a}}$ & $131.4 \pm 4.5^{\mathrm{a}}$ & $122.6 \pm 16.3^{\mathrm{a}}$ & $234.7 \pm 38.9^{\mathrm{b}}$ & $221.0 \pm 26.8^{\mathrm{b}}$ \\
Carbohydrate & $15.3 \pm 1.1^{\mathrm{a}}$ & $12.0 \pm 0.6^{\mathrm{a}}$ & $11.6 \pm 2.6^{\mathrm{a}}$ & $18.2 \pm 4.6^{\mathrm{a}}$ & $15.8 \pm 3.0^{\mathrm{a}}$
\end{tabular}

529 Values $( \pm \mathrm{SD})$ with different superscript letters are significantly different $(P<0.05)$. 
532

533

534

535

536

537

538

539

540

541

542

543

544

545

546

547

548

549

550

\section{FIGURE LEGENDS}

Fig. 1. Shell length of Pecten maximus larvae fed different diets as a function of the day post fertilization (mean $\pm \mathrm{SD} ; \mathrm{n}=3$ replicate tanks per diet). See text for diet abbreviations.

Fig. 2. Survival of Pecten maximus larvae fed different diets as a function of the day post fertilization (mean $\pm \mathrm{SD} ; \mathrm{n}=3$ replicate tanks per diet). See text for diet abbreviations.

Fig. 3. Occurrence of double rings in Pecten maximus larvae fed $\mathrm{PTC}, \mathrm{PTC} * \mathrm{G}, \mathrm{PTC} * \mathrm{C}$, PTCR or PTS a function of the number of days post fertilization (mean \pm SD; $n=3$ replicate tanks per diet). Different letters indicate significant differences. See text for diet abbreviations.

Fig. 4. Ash-free dry weight (ng larvae ${ }^{-1}$ ) of Pecten maximus larvae fed PTC, PTC ${ }^{*} \mathrm{G}$, $\mathrm{PTC}^{*} \mathrm{C}, \mathrm{PTCR}$, or PTS at 21 days post fertilization (mean $\pm \mathrm{SD} ; \mathrm{n}=3$ replicate tanks per diet). Different letters indicate significant differences between diets. See text for diet abbreviations.

Fig. 5. Relative concentrations of lipids, proteins and carbohydrates of Pecten maximus larvae fed $\mathrm{PTC}, \mathrm{PTC} * \mathrm{G}, \mathrm{PTC} * \mathrm{C}, \mathrm{PTCR}$, and PTS at 21 days post fertilization (mean $\pm \mathrm{SD}, \mathrm{n}=3$ replicate tanks). See text for diet abbreviations. 
Figure(s)
Click here to download high resolution image

FIG 1

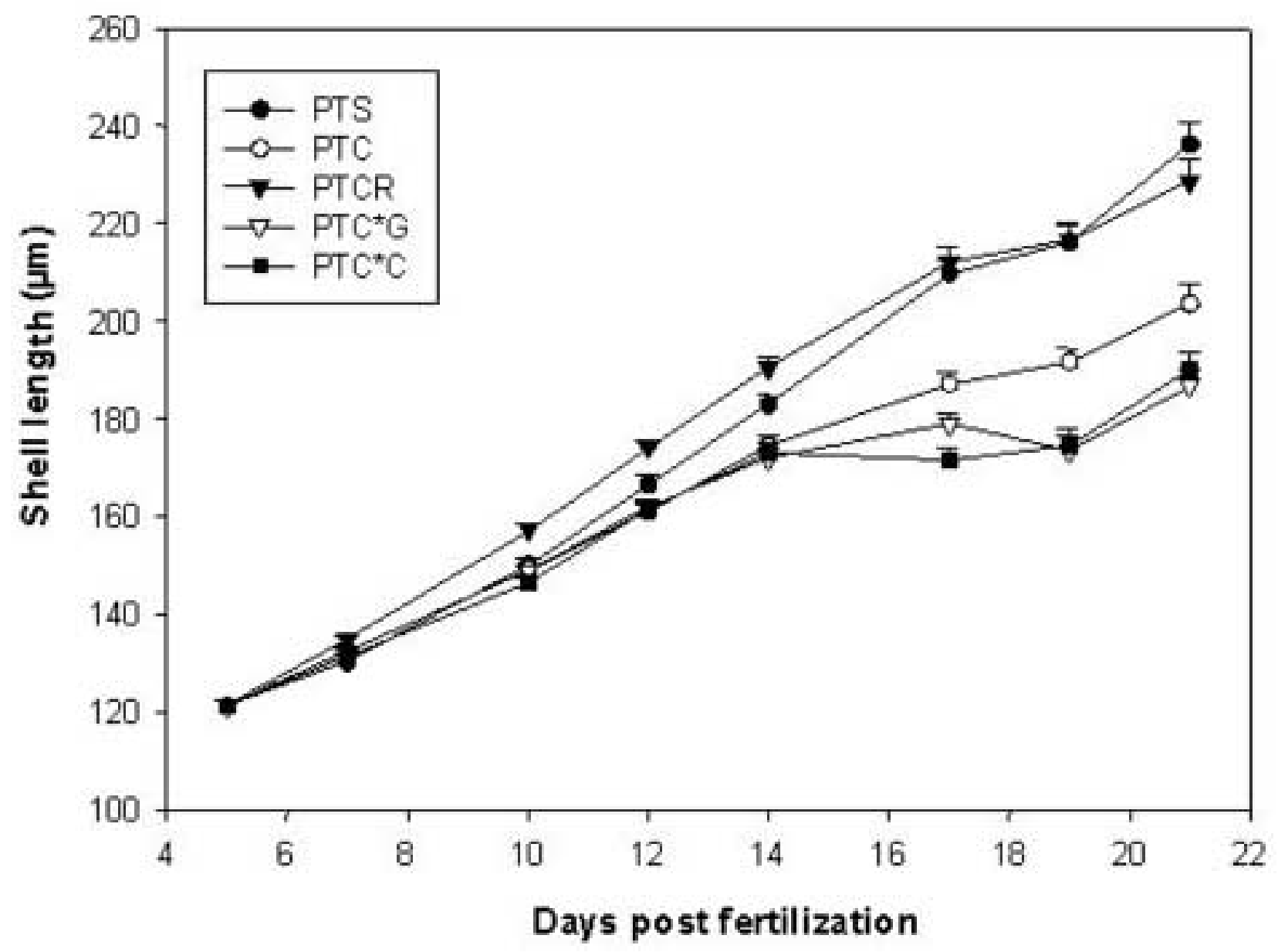


Click here to download high resolution image

FIG 2

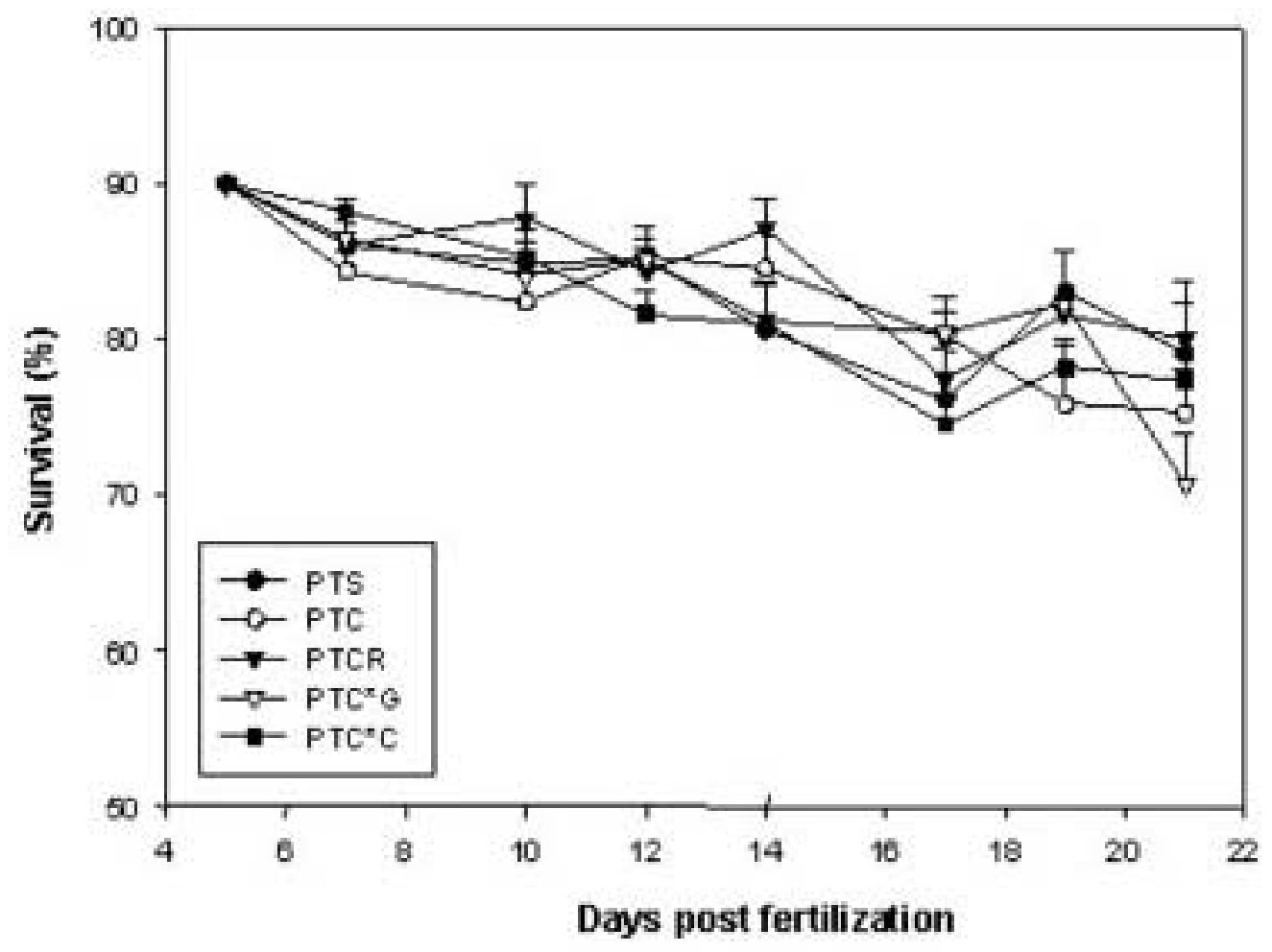


Figure(s)
Click here to download high resolution image

Fig. 3

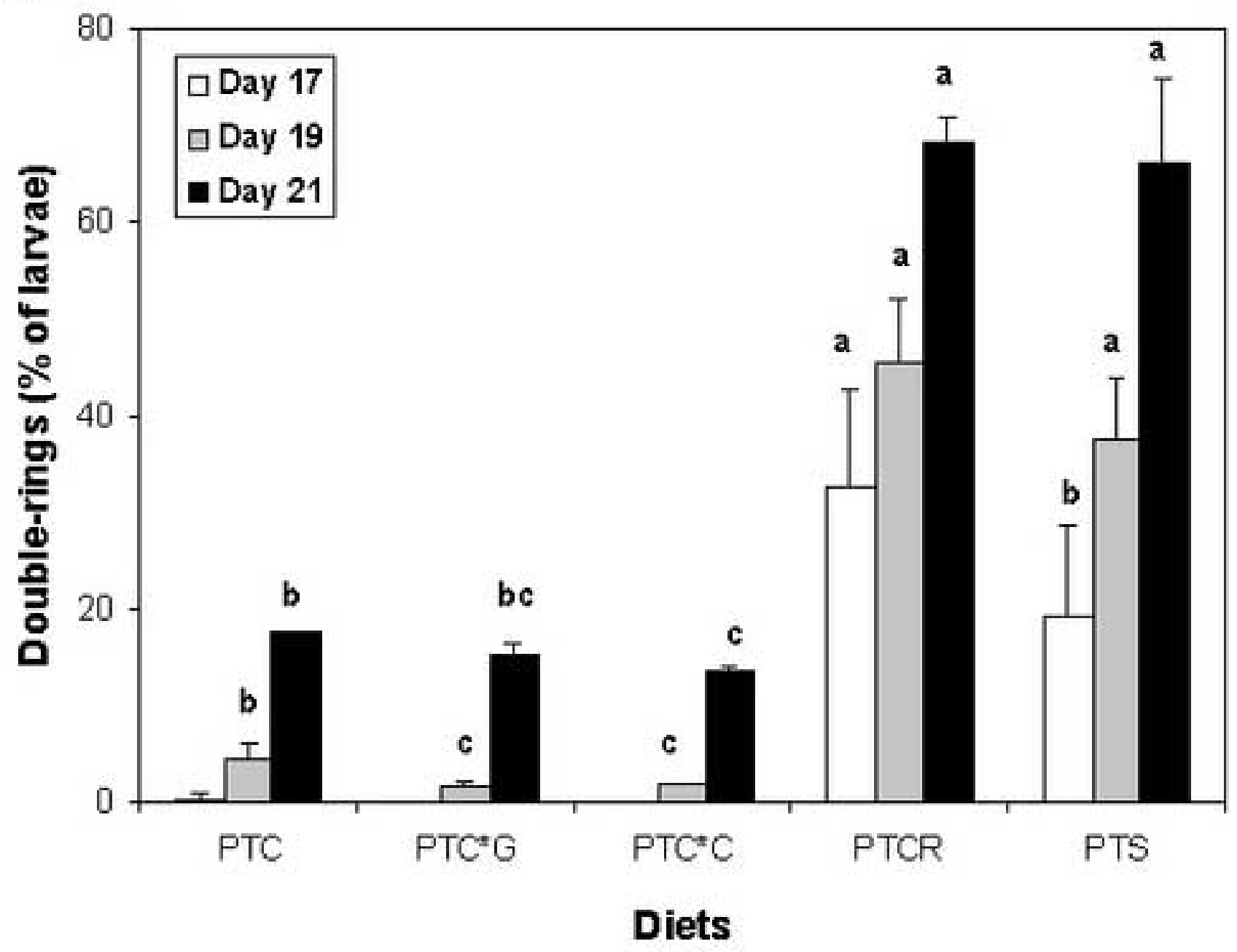


Figure(s)
Click here to download high resolution image

Fig 4.

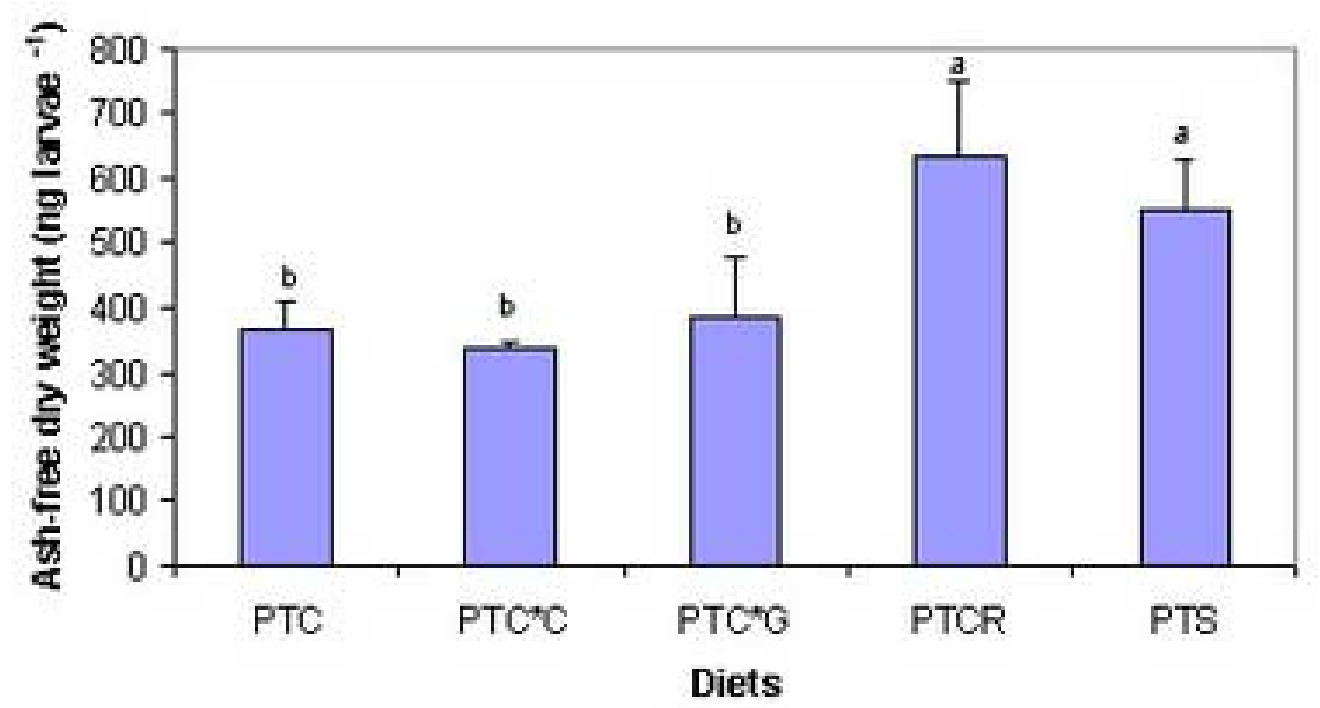




\section{Figure(s)}

Click here to download high resolution image

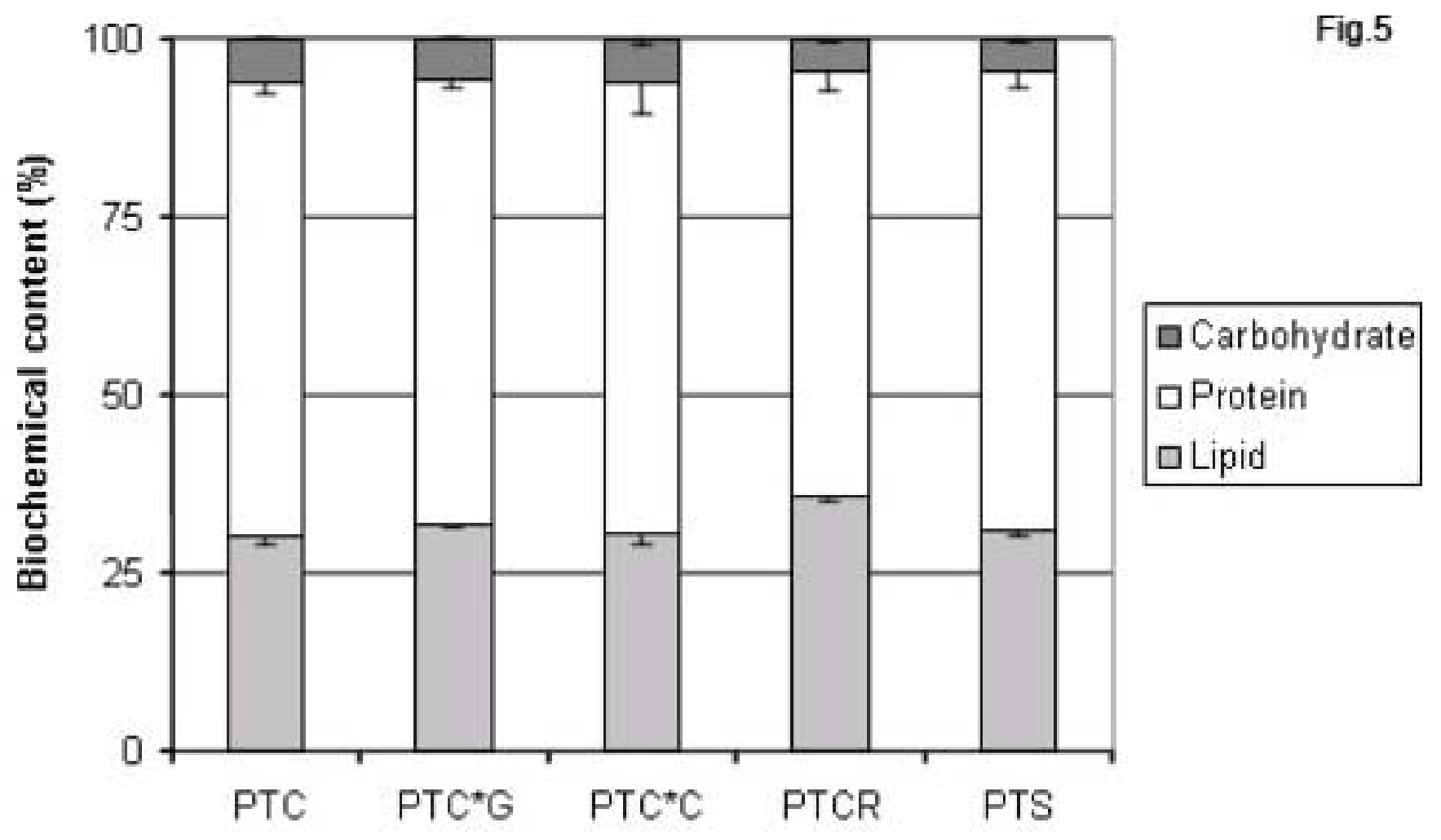

Diets 
Ms. Ref. No.: AQUA-D-06-00612

Title: Effect of Rhodomonas salina addition to a standard hatchery diet during the early ontogeny of the scallop Pecten maximus

As requested, all comments of the two reviewers have been included. The details of our modifications are described below following the reviewers' comments.

Reviewer \#1:

1. p. 2, line 45-47. The statement "This high level of organic matter in the form of lipids seems to promote larvae to grow and to complete metamorphosis more rapidly than with the other diets" -seems to imply that this (R. salina) diet contained more lipid, when in fact it was the larvae. The accumlation of lipid was likely to have resulted as a consequence of better growth with the R.salina diet, with the larvae accumulating lipid during ontogeny. This point needs to made clear; currently it is a little confusing.

We agree and therefore modified the sentence for: Moreover, our results showed that the addition of $R$. salina significantly improved the overall condition of the larvae by promoting an increase in organic matter and total lipids. This accumulation of lipids during ontogeny seems to promote larvae to grow and to complete metamorphosis more rapidly than with the other diets.

2. p. 4, line 88: size of broodstock scallops, if available.

The sizes are not available, but we have added wet weight.

3. p. 4, lines 91 and 92: More information would be useful on the process for thermal shock of broodstock (i.e. temperature change and time) - or reference to another paper where it is cited.

A reference to Gruffydd \& Beaumont (1970) has been added.

4. p. 5, lines 103-104: please state light intensity and culture volume

Information added.

5. p. 12, lines 265-266: A value of carbohydrate of $\sim 40 \%$ is cited for R. salina from the study, but no other data for this or other species is given in the paper. For example, how does this $40 \%$ compare with other species examined?

Information from the literature has been added: "...carbohydrate levels in diatoms $(C$. gracilis and S. costatum) and prymnesiophytes (I. galbana and P. lutheri) are generally under 15\% (Brown et al. 1997).

6. p. 25 line 501: "larve" should read "larva"

Done.

7. p. 26 line 503: "larve" should read "larva"

Done.

8. Fig 1: y axis of graph, "lenght" should read "length"

Done. 
9. Fig. 4: y axis of graph, "larvae" should read "larva"

Done.

Reviewer \#2:

General: Several times throughout the ms the full latin name (ie. Rhodomonas salina) is written, even after it has been written in full earlier in the chapter (ie pg2 - line 39, pg12 - line 273, 274, 275,276). Please correct and shorten (ie. R. salina and similar).

Done.

Pg1 - line 29: Keywords: perhaps fatty acids or algal fatty acids could be included? Done.

Pg2 - line 33-36 Abstract: I think first sentence should be re-phrased, as it seems a bit long. Done.

- line 45: Consider using the word "increase" instead of "enrichment" as the meaning seems more appropriate. Also, consider using "higher" instead of "high" as it is not really shown that this is a high value in general, although it was the highest in your work.

Done.

Pg3 - line 55: It is not clear to me what the authors mean by "Metamorphosis is a stressful series..." Consider deleting "stressful"

Done.

Pg4 - line 76: I suggest that "recently" is changed to "previously", as the reports from 1986 to 1999 hardly can be called recent.

Done.

Pg4 - line 91: I was very disturbed to read "Male and females" concerning the spawning of Pecten maximus as this species is a functional hermaphrodite. Surely, the co-authors from France must know this and cannot have read the manuscript thoroughly.

Corrected.

- line 93: was there any particular reason for using the $21<\mathrm{mu}>\mathrm{m}$ mesh size to collect veliger larvae? Normally a $45<\mathrm{mu}>\mathrm{m}$ mesh size is used.

This was an error and is now corrected.

-line 95: number of replicate beakers should be mentioned here.

Done.

Pg5 - line 99: the abbreviation for "days post fertilization", dpf, should rather be moved to the beginning of the chapter Material and methods", and used consistently thereafter (it is not on pg. 10 , line 235 and pg 11 line 236).

Done. 
- line 105: consider using similar ratio signs for both gases and volumes, ie "air:CO2=98.5:1.5\%" (or similar).

Done.

- line 113: It is interesting to know if the daily ration of feed was distributed once or twice a day. Please add the information.

Done.

- lines 114-115: It is very unclear why the total number of cells fed to the larvae was not the same for all diets. This would have excluded one factor to consider when interpreting the results. Neither the cell number nor the dry weight of the feed rations is similar, and this is very hard to understand. In my opinion this is one of the serious weaknesses of the work. Normally an algal cell concentration higher than $20-40$ cells $/<\mathrm{mu}>1$ will be saturating for scallop larval ingestion rate (ie. Lu and Blake, 1997). This means that increasing cell concentration above this will finally cause an overload of particles for larval feeding, and hence, decrease ingestion rate. The concentration of 165 cells $/<\mathrm{mu}>1$ may or may not cause the ingestion rate to decrease. Also, the increased feed concentrations causes water quality problems even for as short term as 2-3 days. I strongly feel that possible effects of different cell concentrations in your diets should be included in the discussion.

The two additional control diets $\left(\mathrm{PTC}^{*} \mathrm{C}\right.$ and $\left.\mathrm{PTC}^{*} \mathrm{G}\right)$ were tested to account for the higher biomass of the PTCR diet, but with the larger cells of $R$. salina, it was impossible to test the effect of similar biomass without increasing the cell concentration. The differences in cell concentration and biomass of the diets are already discussed (Page 13, line 293-300) in relation to the saturation of the filtration system. But as suggested, results from the $\mathrm{Lu}$ and Blake study have been added and discussed.

Pg6 - line 125: mention here that samples were taken from all larval units ( $\mathrm{n}=3$ for each diet). Done.

- line 126: consider changing "recovered" to "collect" as recover rather means to "get well". Done.

- line 131: add how many individuals were measured from each larval unit $(\mathrm{n}=$ ?).

Done.

- line 137: from your description of methods, the organic matter is ash-free dry weight and I suggest you use that expression. - line 139: add the duration of heating at $450 \mathrm{C}$ (hours?)

Done.

Pg7 - line 145-146: Even if PT was similar for all diets, I believe that you should have described the quality (FA) of each diet instead of only the species that were different from diet to diet. Then you would have seen the actual ratio of differences in fatty acids between the diets. Now, even if $\mathrm{R}$ have a double amount of a fatty acid compared to $\mathrm{C}$, it does not necessarily give the same picture for the diet because the ratio of the species (as \% of total number of cells) differs between the diets (ie. In PTCR R is $1 / 4$ of the total cells, in PTC C is $1 / 3$ of the total cells).

As flagellates were not sampled, it is not possible to add these analyses. However, we added in this section that the biochemical content of these flagellates has been presented in the 
literature (Delauney et al. 1993, Soudant et al. 1996, Brown et al. 1997, Soudant et al. 2000).

- line 146: what was the number of replicates for the algal samples?

Three; this has been added to the text.

- line 147: the size (mm?) for the GF/F filters?

$25 \mathrm{~mm}$; this has been added to the text.

- line 148: the total volume of the glass tubes? And the volume used of the chloroform:methanol mix? - line 153: Do you mean that samples were evaporated to dryness, or actually the lipids? Also, was the ratio of chloroform:methanol again based on volume (v:v)? Please add this to your text.

Done.

Pg8 - line 172: Consider changing the word "Pools" to "Samples", and was only one sample collected from each tank? Please add in text - line 173: the size of the GF/F filter (mm?) - line 176: How many $\mathrm{ml}$ of ammonium formate was used to rinse each filter with larvae? - line 181189 Statistics: What statistics were used for larval fatty acids?

This information has been added in the text.

Pg9 - Line 198-199 Results: The first sentence can be deleted as the same thing is explained in Material and Methods. - line 200: in parenthesis it says that TFA is given as ng/cell, but in the table 1 it says pg/cell. Correct what is wrong.

Done and corrected for $\mathrm{pg} / \mathrm{cell}$.

Pg10 - line 213: Only one sterol conc. is given for R. salina, so it should all be in singular ("concentration" and "was")

Corrected.

- line 215: unless all microalgal spp are characterized by high sterol concentrations, a "the" must be put in front of "microalgal species" to get the meaning "the three spp you have used here".

Corrected.

- line 223-225 Scallop performance: the shell height is given in Figure 1, but it could be interesting to know the mean growth rate as well. It always indicates if the larval groups seemed healthy or not. Perhaps just given in the text. - line 227-228: Figure 2 gives \% survival, and so this is what it should be referred to in the text as well (it says "cumulative mortality").

Done.

Pg11 - line 241-254: I suggest as earlier that you use the term ash-free dry weight instead of OM, and also change "scallop" with "larvae" in this paragraph. The word "concentration" should be changed to "content" as you describe the amount per individual. It is also confusing to read about $\%$ differences on absolute values. Perhaps it could be given in parts?

Modifications made as requested.

Pg12 - line 264: delete "global" - line 265: change "contained" to "content" - line 267: 
"developmental metabolism" is unclear to me. May need to rephrase. - line 272: is the volume of R.salina really "very large"? Not compared to larger algae, so perhaps you could rephrase it to "larger" as it was larger than the other algae in your study (but they are actually small algae).

Done.

Pg.13 - line283-285: the effect of high concentrations (up to 165 cells $/ \mathrm{ml}$ ) of algal cells on larvae is mentioned for your study, but you should also mention the level of concentration that was reported by Sprung $(1984,1989)$. I am not convinced that reports for adults are interesting in this context, as the feeding and ingestion varies from larvae to adults. I suggest that you find more references concerning bivalve larvae and rather delete the information about adults. - line 287288: consider to change "resulted from" to "may have resulted from" as the results are only indicative. Also, I would not call 60 cells $/<\mathrm{mu}>1$ "low cells concentration", as indicated by a rather large number of reports about the cultivation of P. maximus larvae (ie Robert et al.). - line 293: Delete "Other" as there are no other "qualitative differences" to refer to.

Done.

Pg14 -line 313: you should add "only" after "diatoms" as the reference by Delaunay et al. is about monospecific diets.

Done.

Discussion:

In addition to expend the discussion about the possible effect of different cell concentrations for the different diets, the use of antibiotics should also be mentioned. Adding antibiotics to larval units of small volumes may seem necessary to ensure larval survival. However, have you investigated if the antibiotic affects the larvae in any way?

We did not investigate the effects of antibiotics in this study; however, it has been discussed in literature. This text has been added at the end of the first paragraph of the discussion:

"The increased feed concentrations may cause water quality problem by bacteria proliferation. Nevertheless, the use of antibiotics to ensure the success of $P$. maximus larval culture seems to limit this problem, as no more mortality was observed in these treatments. The use of antibiotics at a concentration of $8 \mathrm{mg} \cdot \mathrm{L}^{-1}$ has been demonstrated to be beneficial for the survival of scallop larvae with no impact on the growth rate (Nicolas et al. 1996, Robert et al. 1996)."

Pg18 - line 413 References: Knauer et al. 1998 cannot be found in the text. Delete if that is the case.

Done.

Tables.

Pg 22 Table 1: In addition to what is noted in the table text, there are also 3 ratios (n-3/n-6 etc.) and TFA as pg/cell. Should be included in the table text.

Done.

Pg25 Table 4: -line 498: after "absolute" I suggest you add (ng larvae-1) and similar after "relative", instead of at the bottom of the table. - line 498 and 501: change "concentrations" to "values"

Done. 
Pg26 Table 5: - line 502: Delete "Quantitative proportion of" - line 503: move 1) (ng larvae-1) and 2) "at day 21", to after "larvae" in line 502. Also, rather add "means + SD" on this line Done.

Figure legends.

Pg27 - line 509: delete "on"- line 509-510: Add "note that both axes do not begin at 0". - line 511: Is survival given as \% of day 4 number? Please explain. Delete "on". Add "note that both axes do not begin at 0"- line 513: What is occurrence of double rings given as a \% of? Please explain. - line 521: Also the relative concentrations of lipids, etc - as \% of what?

Done. The survival rate beginning at 90\% represents the mortality observed between hatching and the beginning of the nutritional experiment after transfer to the IFREMER hatchery, as described in the material and methods section (line 131-132).

\section{FIGURES}

Fig 3. Y-axis title should be of similar format as \#1 and \#2 (ie. Double-rings (\% of ?)). Done.

Fig 4. Y-axis title should be of similar format as \#1 and \#2 (Ash-free dry weight (ng larvae-1) Done.

Fig 5. Y-axis should have the "\%" at the end of the title (Biochemical content (\% of ?)) Done. 